\title{
Cannabinoids Activate Monoaminergic Signaling to Modulate Key C. elegans Behaviors
}

\author{
Mitchell D. Oakes, ${ }^{1}$ Wen Jing Law, ${ }^{1}$ OTobias Clark, ${ }^{1}$ Bruce A. Bamber, ${ }^{1}$ and Richard Komuniecki ${ }^{1}$ \\ Department of Biological Sciences, University of Toledo, Toledo, Ohio 43606
}

Cannabis sativa, or marijuana, a popular recreational drug, alters sensory perception and exerts a range of potential medicinal benefits. The present study demonstrates that the endogenous cannabinoid receptor agonists 2-arachidonoylglycerol (2-AG) and anandamide (AEA) activate a canonical cannabinoid receptor in Caenorhabditis elegans and also modulate monoaminergic signaling at multiple levels. 2-AG or AEA inhibit nociception and feeding through a pathway requiring the cannabinoid-like receptor NPR-19. 2-AG or AEA activate NPR-19 directly and cannabinoid-dependent inhibition can be rescued in $n p r-19$-null animals by the expression of a human cannabinoid receptor, $\mathrm{CB}_{1}$, highlighting the orthology of the receptors. Cannabinoids also modulate nociception and locomotion through an NPR-19-independent pathway requiring an $\alpha_{2 \mathrm{~A}}$-adrenergic-like octopamine (OA) receptor, OCTR-1, and a 5-HT ${ }_{1 \mathrm{~A}}$-like serotonin (5-HT) receptor, SER-4, that involves a complex interaction among cannabinoid, octopaminergic, and serotonergic signaling. 2-AG activates OCTR-1 directly. In contrast, 2-AG does not activate SER-4 directly, but appears to enhance SER-4-dependent serotonergic signaling by increasing endogenous 5-HT. This study defines a conserved cannabinoid signaling system in C. elegans, demonstrates the cannabinoid-dependent activation of monoaminergic signaling, and highlights the advantages of studying cannabinoid signaling in a genetically tractable whole-animal model.

Key words: cannabinoid; C. elegans; monoamine; neuromodulation; nociception

\section{Significance Statement}

Cannabis sativa, or marijuana, causes euphoria and exerts a wide range of medicinal benefits. For years, cannabinoids have been studied at the cellular level using tissue explants with conflicting results. To better understand cannabinoid signaling, we have used the Caenorhabditis elegans model to examine the effects of cannabinoids on behavior. The present study demonstrates that mammalian cannabinoid receptor ligands activate a conserved cannabinoid signaling system in C. elegans and also modulate monoaminergic signaling, potentially affecting an array of disorders, including anxiety and depression. This study highlights the potential role of cannabinoids in modulating monoaminergic signaling and the advantages of studying cannabinoid signaling in a genetically tractable, whole-animal model.

\section{Introduction}

Cannabis sativa, or marijuana, has long been a popular recreational drug because of its unique ability to alter sensory perception and cause euphoria. More importantly, marijuana also has been reported to exert a wide range of medicinal effects (Pacher et al., 2006). Cannabis contains $>60$ bioactive compounds, or phytocannabi-

Received Oct. 11, 2016; revised Jan. 22, 2017; accepted Feb. 1, 2017.

Author contributions: M.D.O., B.A.B., and R.K. designed research; M.D.O., W.J.L., and T.C. performed research; B.A.B. and R.K. contributed unpublished reagents/analytic tools; M.D.O., W.J.L., T.C., and R.K. analyzed data; M.D.O. and R.K. wrote the paper.

This work was supported by the National Institutes of Health (Grant Al072644 to R.K.) and by funds from the Joan L. and Julius H. Jacobson Biomedical Professorship. We thank Dr. Robert Steven, Dr. Tomer Avidor-Reiss, and Dr. Vera Hapiak for reviewing and editing the manuscript and the C. elegans Genetics Center and the National Bioresources Center for null strains.

The authors declare no competing financial interests.

Correspondence should be addressed to Richard Komuniecki, Department of Biological Sciences, University of Toledo, 2801 W. Bancroft Street, Toledo, OH 43606. E-mail: rkomuni@uoft02.utoledo.edu.

DOI:10.1523/JNEUROSCI.3151-16.2017

Copyright $\odot 2017$ the authors $\quad 0270-6474 / 17 / 372859-11 \$ 15.00 / 0$ noids, the two most common being $\Delta^{9}$-tetrahydrocannabinol (THC) and cannabidiol (CBD). In addition, the endogenous cannabinoids 2-arachidonoylglycerol (2-AG) and $N$-arachidonoylethanolamine (anandamide or AEA) are synthesized within the brain and CNS. Cannabinoids primarily activate $\mathrm{G} \alpha_{\mathrm{o}}$-coupled cannabinoid receptors 1 and $2\left(\mathrm{CB}_{1}\right.$ and $\left.\mathrm{CB}_{2}\right) \cdot \mathrm{CB}_{1}$ is localized primarily to the brain and CNS (Herkenham et al., 1990; Glass et al., 1997; Martin et al., 1998), whereas $\mathrm{CB}_{2}$ is restricted to the periphery and certain leukocytes (Munro et al., 1993). Endocannabinoids and phytocannabinoids activate the same receptors and elicit similar cellular responses despite their structural differences. Both 2-AG and AEA mediate retrograde inhibition of synaptic neurotransmission via activation of $\mathrm{CB}_{1}$ on presynaptic membranes (Ohno-Shosaku and Kano, 2014).2-AG or AEA inhibition is terminated by monoacylglycerol lipase (MAGL) or fatty acid amide hydroxylase (FAAH), respectively, with inhibition of either, eliciting analgesic and antinociceptive behavior (Piomelli et al., 2006; Long et al., 2009a; Long et al., 2009b). 
Thus far, the majority of studies on cannabinoids have been conducted at the cellular level, sometimes using mammalian tissue explants to observe receptor activation. In contrast, our goal was to examine the role of cannabinoids on whole-animal behavior and to dissect the role of cannabinoid signaling in the modulation of sensory integration and downstream decision making. Therefore, the present study was designed to examine the effects of cannabinoid receptor agonists on nociceptive behaviors in the nematode (C. elegans) model system because $\mathrm{CB}_{1}$ appears to suppress pain in mammals (Sofia et al., 1973; Yaksh and Reddy, 1981; Tsou et al., 1995; Walker and Huang, 2002).

Our results demonstrate that mammalian cannabinoid receptor ligands activate a conserved cannabinoid signaling system in C. elegans and also modulate monoaminergic signaling, potentially affecting an array of disorders, including anxiety and depression. In contrast to published reports, C. elegans contains an endogenous canonical cannabinoid signaling system (McPartland and Glass, 2001; Pastuhov et al., 2016). Inhibiting the breakdown of endogenous 2-AG or AEA mimics 2-AG or AEA addition and inhibits nociception and feeding through a pathway that requires the cannabinoid-like receptor NPR-19. Cannabinoids activate NPR-19 directly and npr-19-null animals can be rescued by the expression of human $\mathrm{CB}_{1}$, confirming the orthology of the two receptors. In addition, higher exogenous cannabinoid levels also activate an $\alpha_{2 \mathrm{~A}}$-adrenergic-like receptor (OCTR-1) and a 5- $\mathrm{HT}_{1 \mathrm{~A}}$-like receptor (SER-4) to modulate both nociception and locomotion through NPR-19-independent pathways. Cannabinoids activate OCTR-1 directly when expressed heterologously in Xenopus laevis oocytes. In contrast, 2-AG does not activate SER-4 directly and cannabinoids appear to enhance SER-4-dependent serotonergic signaling by increasing endogenous serotonin (5-HT). This study highlights the potential role of cannabinoids in modulating monoaminergic signaling and the advantages of studying cannabinoid signaling in a genetically tractable, whole-animal model.

\section{Materials and Methods}

Nematode strains and construction of C. elegans transgenes. Strains were maintained as described in Brenner (1974). The following strains were used: N2 (Bristol), ckr-2 (tm3082), dop-1 (ok298), mod-5 (n3314), npr-3 (tm1583), npr-5 (ok1583), npr-19 (ok2068), npr-24 (ok3192), octr-1 (ok371), ser-2 (pk1357), ser-4 (ok512), and tph-1 (n4622). RNAi transgenes were generated by PCR fusion as described in Esposito et al. (2007) and coinjected with $f 25 b 3.3:: g f p$ (to $100 \mathrm{ng}$ ). The octr-1 (+), npr-19(+) full-length genomic and $n p r-19:: n p r-19:: g f p$ transcriptional transgenes were generated by PCR fusion and coinjected with $f 25 b 3.3:: g f p$ (to $50 \mathrm{ng}$ ). The $n p r-19:: g f p$ transcriptional transgene was constructed by PCR fusion of $1.5 \mathrm{~kb} n p r-19$ promoter including the first intron fused to $g f p:: u n c-54$ $3^{\prime \prime}$-UTR and coinjected with unc-122::rfp (to $50 \mathrm{ng}$ ). The npr-19::CNR1:: $g f p$ transgene was generated by 3 -piece PCR fusion of the $n p r-19$ promoter including the first intron, full-length human CNR1 cDNA, and gfp::unc-54 $3^{\prime \prime}$-UTR and were coinjected with unc-122::rfp (to $50 \mathrm{ng}$ ). unc-17 $\beta$-driven transgenes were generated by PCR fusion of the $u n c-17 \beta$ promoter (562 bp) to GPCR cDNA and gfp::unc-54 $3^{\prime \prime}$-UTR and coinjected with unc-122::rfp (to $50 \mathrm{ng}$ ). npr-9::ser-4::gfp transgene was generated by PCR fusion using native $n p r-9$ promoter and coinjected with unc-122::rfp (to $50 \mathrm{ng}$ ). PCR fusions were performed as described in Hobert (2002).

Octanol avoidance assays. Octanol avoidance assays were performed as described in Chao et al. (2004) and as modified by Harris et al. (2011). For all behavioral assays, L4 stage animals were picked $24 \mathrm{~h}$ before assaying. 2-AG and AEA plates were prepared $10 \mathrm{~min}$ before assay by spreading $60 \mu \mathrm{l}$ of 2-AG or AEA (in $\mathrm{H}_{2} \mathrm{O}$ ) on fresh NGM plates. To measure aversive responses to 1-octanol, the blunt end of a hair was briefly dipped in 1-octanol and placed in front of a forward-moving worm and the time taken to initiate backward locomotion was recorded. Animals were first transferred to intermediate (nonseeded) plates, left for $30 \mathrm{~s}$, transferred to assay plates, and tested after $10 \mathrm{~min}$. In all assays, 20-25 worms were examined for each strain and condition and each assay was performed at least three times. Statistical analysis was performed using mean \pm SE and Student's $t$ test.

Heterologous expression and electrophysiology in X. laevis oocytes. The human $\mathrm{CB}_{1}$ (CNR1), $\alpha_{2 \mathrm{~A}}$-adrenergic (ADRA2A), 5- $\mathrm{HT}_{1 \mathrm{~A}}$ (HTR1A), GIRK1, GIRK2, and C. elegans npr-19, octr-1, and ser-4 cDNAs were cloned between Not1 and Agel restriction enzyme sites into a Xenopus expression vector containing a T7 promoter and the Xenopus $5^{\prime}$ and $3^{\prime}$ $\beta$-globin UTRs to generate $p x G I R K 1, p x G I R K 2, p x C N R 1, p x A D R A 2 A$, pxHTR1A, pxser-4, pxoctr-1, and pxnpr-19, respectively. Linearized plasmids were transcribed using an Ambion mMessage mMachine T7 kit (Applied Biosystems). ADRA2A, CNR1, GIRK1, and GIRK2 cDNAs were from Addgene and HTR1A cDNA was from GE Healthcare. X. laevis oocytes were from Xenopus One and Nasco. Oocytes were separated mechanically before incubation in ND-96 $\left(\mathrm{Ca}^{2+}\right.$ free $)$ medium $(96 \mathrm{~mm}$

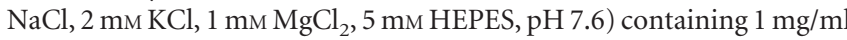
collagenase type 1A (Sigma Aldrich) for $30 \mathrm{~min}$. Defolliculated oocytes were separated and incubated in modified Barth's medium with $1 \mathrm{~mm} \mathrm{Na}$ pyruvate, $0.01 \mathrm{mg} / \mathrm{ml}$ gentamicin, and $1 \times$ antibiotic-antimycotic (Invitrogen) at $16^{\circ} \mathrm{C}$ overnight. Receptor cRNAs were injected at $50 \mathrm{ng} / 50 \mathrm{nl}$ and GIRK1 and GIRK2 channel cRNAs were injected at $0.5 \mathrm{ng} / 50 \mathrm{nl}$. Oocytes were incubated at $16^{\circ} \mathrm{C}$ for $48-72 \mathrm{~h}$ after injection and then transferred to $4^{\circ} \mathrm{C}$. Two-electrode voltage-clamp (TEVC) recordings were performed $72 \mathrm{~h}$ after injection using an Axon Gene Clamp 500 Amplifier (Molecular Devices) as described previously (Stühmer, 1998; Bamber et al., 2003). For TEVC recordings, standard low $\mathrm{K}^{+}$Ringer's solution ( $115 \mathrm{~mm} \mathrm{NaCl}, 2.5 \mathrm{~mm} \mathrm{KCl}, 1.8 \mathrm{~mm} \mathrm{CaCl}_{2}, 10 \mathrm{~mm}$ HEPES, pH 7.2) and a high $\mathrm{K}^{+}$Ringer's solution $(96 \mathrm{~mm} \mathrm{KCl}, 2 \mathrm{~mm} \mathrm{NaCl}, 1.8 \mathrm{~mm}$ $\mathrm{CaCl}_{2}, 10$ mm HEPES, pH 7.2) were applied by gravity perfusion. Ligands were applied by gravity perfusion initially at $1 \mu \mathrm{M}$. Oocytes coexpressing GIRK1/2 and GPCRs were perfused with intervals of increasing concentrations of 2-AG and AEA to determine ligand specificity and $\mathrm{EC}_{50} \cdot 2-\mathrm{AG}$ and AEA dose-response curves were fitted with the equation: $I-I_{\max } / / 1$ $\left.+10^{(\log \mathrm{EC} 50-[\text { agonist] }) \times n}\right)$, where $I$ is the current at a given $2-\mathrm{AG}$ or AEA concentration, $I_{\max }$ is current at saturation, $\mathrm{EC}_{50}$ is the 2-AG and AEA concentration required to elicit half-maximal current, and $n$ is the slope coefficient. Curve fitting was performed using GraphPad Prism software.

Confocal imaging. To localize NPR-19, a transcriptional npr-19::gfp transgene was generated using $1.5 \mathrm{~kb}$ upstream of the predicted $n \mathrm{pr}-19$ start site, including the first intron. To identify a subset of amphid sensory neurons, animals were incubated in $5 \mu \mathrm{M} 1,1^{\prime}$-dioctadecyl-3,3,3', $3^{\prime}$ tetramethylindodicarbocyanine (DiD; Invitrogen) for $1 \mathrm{~h}$ and then transferred to a standard NGM plate seeded with OP50 for $1 \mathrm{~h}$ to destain. For neuronal identification, $n p r-19:: g f p$ was coinjected with $t p h-1:: r f p$, $t d c-1:: r f p, f l p-8:: r f p, f l p-18:: r f p$, or $c e h-36:: r f p$. All imaging was performed on an Olympus IX81 inverted confocal microscope. Animals expressing the $n p r-19:: g f p$ transgene were immobilized on agarose pads with $20 \mathrm{~mm}$ sodium azide and imaged for GFP/RFP/DiD fluorescence.

Pharyngeal pumping assay. Pharyngeal pumping was assayed on NGM plates. 2-AG plates were prepared $10 \mathrm{~min}$ before assay by spreading $60 \mu \mathrm{l}$ of $320 \mu \mathrm{M} 2-\mathrm{AG}$ (in $\mathrm{H}_{2} \mathrm{O}$ ) on fresh, predried NGM plates. For all pumping assays, L4 animals were picked $24 \mathrm{~h}$ before assay. Animals were moved from food plates to either a nonseeded NGM plate for control or 2-AG plates and incubated for $10 \mathrm{~min}$. During assay, locomotion was recorded using a Sony Exwave HAD color-video digital camera for $2 \mathrm{~min}$. Videos were played back in slow motion and the number of pharyngeal pumps per minutes was counted. Statistical analysis was performed using mean \pm SE and Student's $t$ test.

Feeding assay. Uptake of fluorescently labeled latex beads was performed as described in Kiyama et al. (2012). Fluoresbrite YG Microspheres were from Polysciences $(1.00 \mu \mathrm{m}$; catalog \#17154-10), diluted in ethanol, and stored at $4^{\circ} \mathrm{C}$. Feeding plates were made by spreading $150 \mu \mathrm{l}$ of M9 bead solution $\left(1 \times 10^{8}\right.$ microspheres/plate $)$ and drying for $30 \mathrm{~min}$. Wild-type and $n p r$-19-null animals were incubated for $10 \mathrm{~min}$ on plates containing 2-AG, AEA, or no drug. Animals were transferred to bead plates $\pm 2-\mathrm{AG}$ or AEA, allowed to feed for $30 \mathrm{~min}$ at room temperature, and then removed, washed 
A

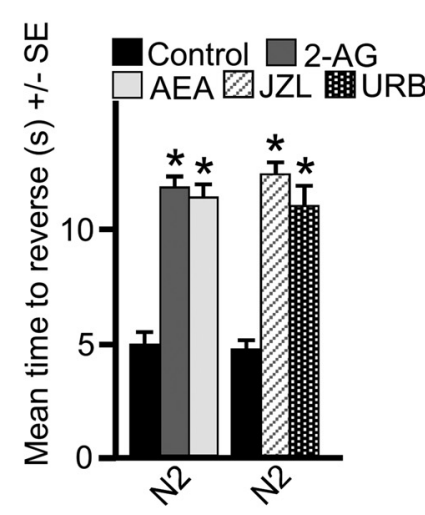

D

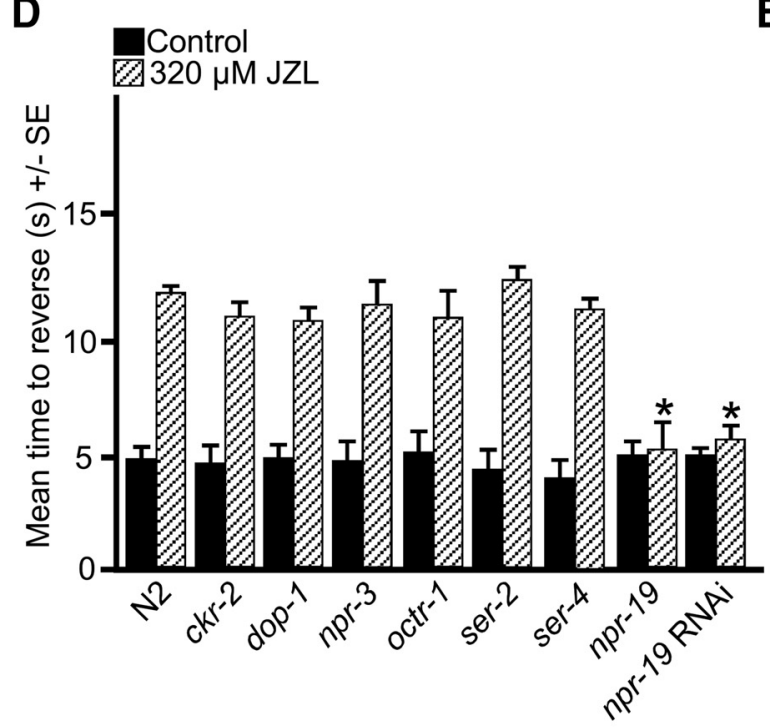

C

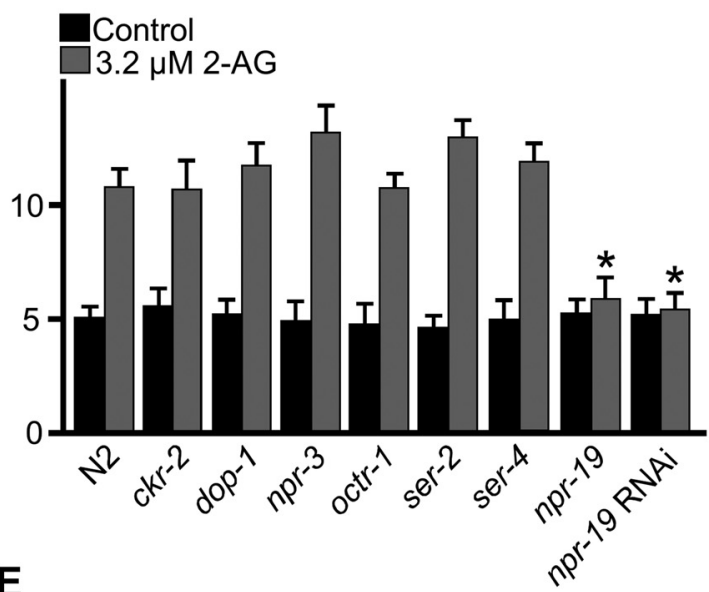

E

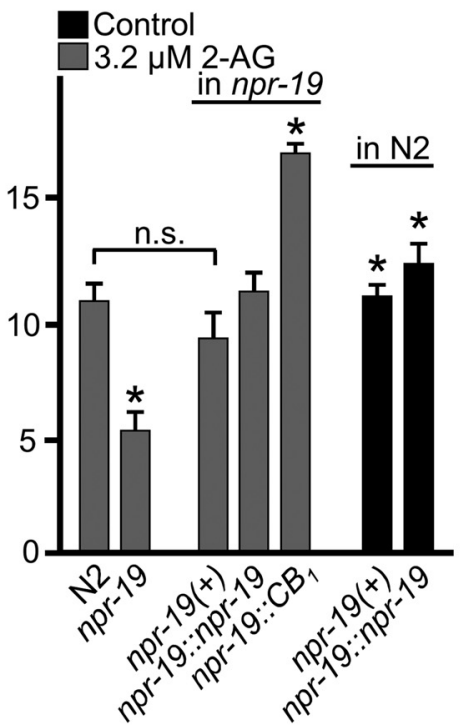

Figure 1. C. elegans contains an endogenous cannabinoid signaling system requiring the cannabinoid receptor NPR-19. The initiation of aversive responses to 1-octanol was examined as described by Harris et al. (2009). A, 2-Arachidonoylglycerol (2-AG), anandamide (AEA), JZL184 (JZL), or URB697 (URB) inhibition of aversive responses to 1-octanol. B, 2-AG dose-response curve for wild-type animals. C, Screen for receptor-null animals resistant to 2-AG-dependent inhibition of aversive responses. $\boldsymbol{D}$, Screen for receptor-null animals resistant to JZL184-dependent inhibition of aversive responses. $E$, $n p r-19$ or $\mathrm{CB}_{1}$ expression driven by a minimal $n p r-19$ promoter in $n p r-19$-null animals. * Significantly different from wild-type animals in the absence of effector ( $p \leq 0.05$ ). Data are presented as a mean $\pm S E(n)$ and were analyzed by two-tailed Student's $t$ test.

with M9 to remove excess beads, and immobilized on agarose pads with 20 mM Na azide for imaging using an Olympus IX81 inverted confocal microscope. Images were analyzed using ImageJ. Statistical analysis was performed using mean \pm SE and Student's $t$ test.

Locomotory (body bend) assay. Freshly poured agar plates (non-NGM) containing either $320 \mu \mathrm{M}$ 2AG/AEA were used for assay. Well-fed, young adult hermaphrodite animals are picked before assay and maintained on NGM plates with E. coli OP50. During assay, seven animals were transferred to the assay plate. Motility was assessed as number of body bend/20 s at $5 \mathrm{~min}$ intervals for $30 \mathrm{~min}$ starting as soon as animals were transferred. Each strain was assayed at least three times with seven animals per assay. Statistical analysis was performed using mean \pm SE and Student's $t$ test.

Endocannabinoid compounds. 2-AG, AEA, JZL184, and URB597 were all from Tocris Bioscience and stock solutions are in DMSO or ethanol at $100 \mathrm{~mm}$ and are stored at $-80^{\circ} \mathrm{C}$.

\section{Results}

Endocannabinoids 2-AG and AEA inhibit aversive behavior 2-AG and AEA have been identified recently in C. elegans extracts by mass spectrometry (Lehtonen et al., 2011), but a simple BLAST search using the human cannabinoid receptor $\mathrm{CB}_{1}$ failed to identify any $C$. elegans receptors with significant identity to $\mathrm{CB}_{1}$, consistent with previous reports that $C$. elegans lacks clear mammalian cannabinoid receptor orthologs (McPartland and Glass, 2001; Pastuhov et al., 2016). In mammals, 2-AG and AEA exert antinociceptive action in models of acute inflammatory and neuropathic pain; therefore, we examined their effects on aversive responses to 1-octanol in C. elegans (Iskedjian et al., 2007; Clapper et al., 2010). This aversive decision-making circuit is mediated primarily by the two ASH sensory neurons and has been characterized extensively (Wragg et al., 2007; Harris et al., 2011; Mills et al., 2012).2-AG and AEA inhibited the more rapid initiation of aversive responses to $100 \% 1$-octanol in C. elegans (2-AG: $t=17.5, \mathrm{df}=$ $16, p<0.0001$; AEA: $t=7.8$, df $=8, p<0.0001)$, with 2 -AG exhibiting an $\mathrm{EC}_{50}$ of $\sim 1 \mu \mathrm{M}$ (Fig. $1 A, B$ ). These relatively high concentrations of ligands were probably necessary to overcome the relative impermeability of the nematode cuticle. 


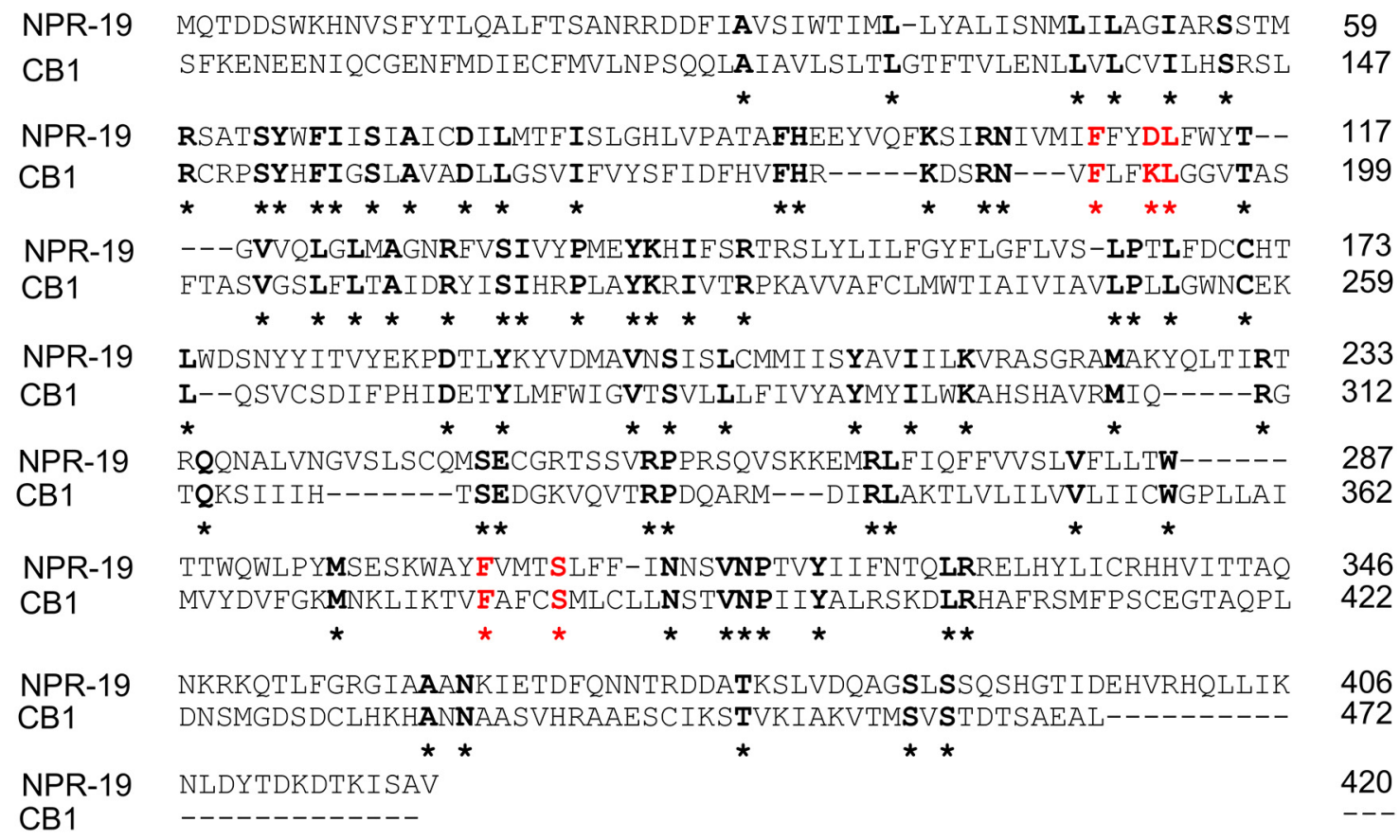

Figure 2. Comparison of CB1 and NPR-19 aa sequences. CB1/NPR-19 protein alignment. Conserved key amino acid residues involved in AEA binding $\left(\mathrm{F}_{189,}, \mathrm{~L}_{193}, \mathrm{~L}_{192}, \mathrm{~F}_{379}\right.$, and $\left.\mathrm{S}_{383}\right)$ are highlighted in red; identical residues are bolded and indicated with an asterisk.

In mammals, the degradation of 2-AG and AEA and termination of signaling are initiated by a membrane-bound MAGL and FAAH, respectively (Long et al., 2009b). The predicted C. elegans proteins, Y97E10AL.2 and FAAH-1, exhibit significant sequence identity to human MAGL (39\%) and FAAH (38\%), respectively, and selective inhibitors are available for both predicted mammalian orthologs (Piomelli et al., 2006; Long et al., 2009a). As anticipated, the inhibition of either MAGL with JZL184 or FAAH with URB597, predicted to inhibit the degradation of 2-AG or AEA, respectively, mimicked 2-AG or AEA addition and inhibited aversive responses to 1-octanol (JZL184: $t=10.1 \mathrm{df}=11, p<$ 0.0001; URB597: $t=20.9, \mathrm{df}=7, p<0.0001$; Fig. $1 A$ ). Together, these results suggest that $C$. elegans contains an endogenous cannabinoid signaling system.

\section{2-AG/JZL184 inhibition of aversive responses is absent in npr-19-null animals}

To identify potential C. elegans cannabinoid receptors, we reexamined protein BLAST data using human $\mathrm{CB}_{1}$ and identified a number of previously characterized $C$. elegans monoamine receptors and predicted neuropeptide receptors, including NPR-19, with limited identity to $\mathrm{CB}_{1}$ (McPartland and Glass, 2001). To determine whether any of these receptors were required for the cannabinoid-mediated inhibition of aversive responses, we screened the appropriate null animals for loss of JZL184 or 2-AG-dependent inhibition of aversive responses (Fig. 1).

JZL184 or 2-AG still inhibited aversive responses in $c k r-2-$, dop-1-, npr-3-, octr-1-, ser-2-, and ser-4-null animals. In contrast, JZL184 or 2-AG inhibition was dramatically reduced in $n p r-19$ null animals (2-AG: $t=10.8, \mathrm{df}=17, p<0.0001$; JZL184: $t=$ 10.3 , df $=12, p<0.0001$; Fig. $1 C, D)$. Similarly, JZL184 or $2-A G$ inhibition was absent after $n$ pr-19 RNAi knockdown (2-AG: $t=$ 10.2, $\mathrm{df}=13, p<0.0001$; JZL184: $t=5.1$, df $=7, p<0.0001)$ using a predicted $1.5 \mathrm{~kb} n p r-19$ promoter (Fig. 1C,D). 2-AG inhibition could be rescued in $n p r-19$-null animals by expression of a full-length $n p r-19$ transgene driven by the predicted $1.5 \mathrm{~kb}$ promoter, including $1 \mathrm{~kb}$ of the $n p r-193^{\prime}$-UTR (Fig. 1E). In addition, wild-type animals overexpressing this $n p r-19$ transgene mimicked the addition of $2-\mathrm{AG}$ and initiated aversive responses more slowly than wild-type animals in the absence of $2-\mathrm{AG}(t=$ $2.8, \mathrm{df}=12, p<0.001$; Fig. $1 E$ ). Importantly, 2-AG sensitivity in npr-19-null animals could also be rescued by the expression of CNR1 cDNA, the human $\mathrm{CB}_{1}$-encoding gene, driven by the $n$ pr-19 promoter described above, confirming the orthology of the two receptors $(t=8.8, \mathrm{df}=12, p<0.0001$; Fig. $1 E)$.

As predicted, although NPR-19 and human $\mathrm{CB}_{1}$ exhibited only $23 \%$ sequence identity, many key amino acids involved in AEA binding appear to be conserved (Fig. 2). The residues delimiting the AEA-binding pocket are largely hydrophobic, based on both modeling and site-directed mutagenesis (Reggio, 2010), and include $\mathrm{F}_{189}, \mathrm{~L}_{193}, \mathrm{~F}_{379}$, and $\mathrm{S}_{383}$. All four residues were conserved in NPR-19 (Fig. 2). $F_{189}$ interacts with the AEA amide oxygen and an $\mathrm{F}_{189 \mathrm{~A}}$ mutation in $\mathrm{CB}_{1}$ decreases AEA binding sixfold (McAllister et al., 2004). The AEA amide oxygen also interacts with a charged residue at position 192 ( $\mathrm{K}$ in $\mathrm{CB}_{1}$, D in NPR-19) and the AEA hydroxyl forms a hydrogen bond with $\mathrm{S}_{383}$ (McAllister et al., 2003).

These data highlight the effective coupling of a human G-proteincoupled receptor to endogenous C. elegans G-proteins and strongly support the hypothesis that NPR-19 is a mammalian cannabinoid receptor ortholog.

\section{2-AG and AEA activate NPR-19 heterologously expressed in Xenopus oocytes directly}

To demonstrate that 2-AG/AEA activate NPR-19 directly, Xenopus oocytes were coinjected with npr-19 and GIRK1/2 cRNAs. GIRK1/2 encode inwardly rectify potassium channel subunits activated by G-protein $\beta \gamma$ subunits and were coexpressed on the assumption that NPR-19 would be $\mathrm{G} \alpha_{\mathrm{o}}$ coupled, based on the observation above that the $\mathrm{G} \alpha_{\mathrm{o}}$-coupled human $\mathrm{CB}_{1}$ rescued aversive phenotypes in $n p r-19$-null animals. As expected, 2-AG 
A

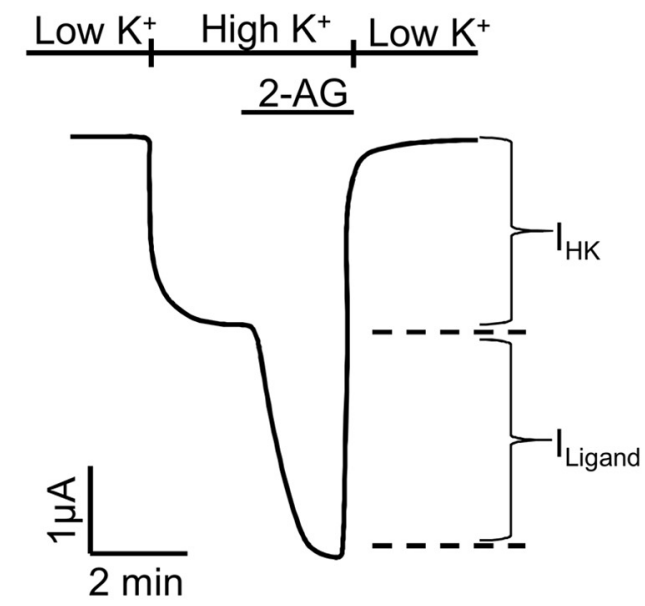

C

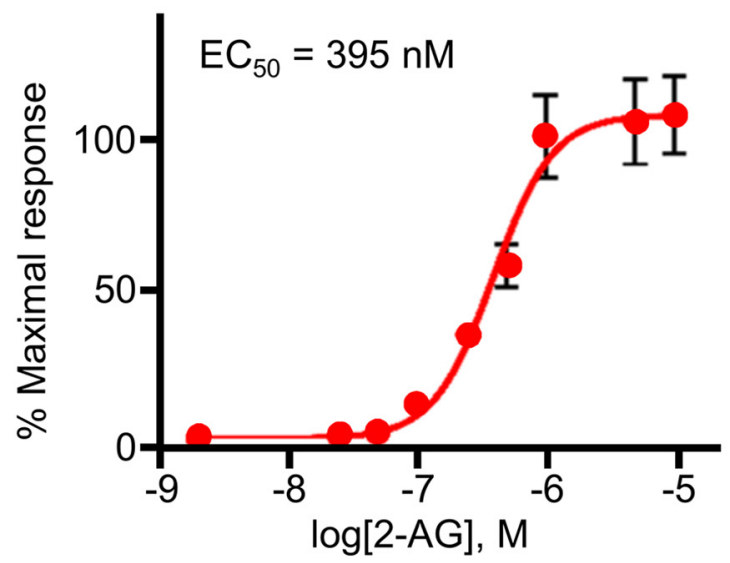

B

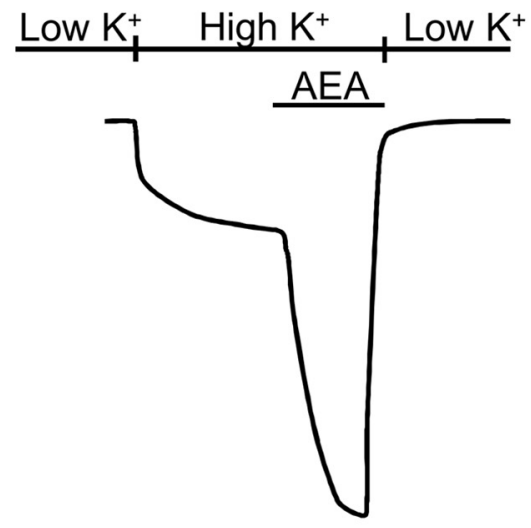

D

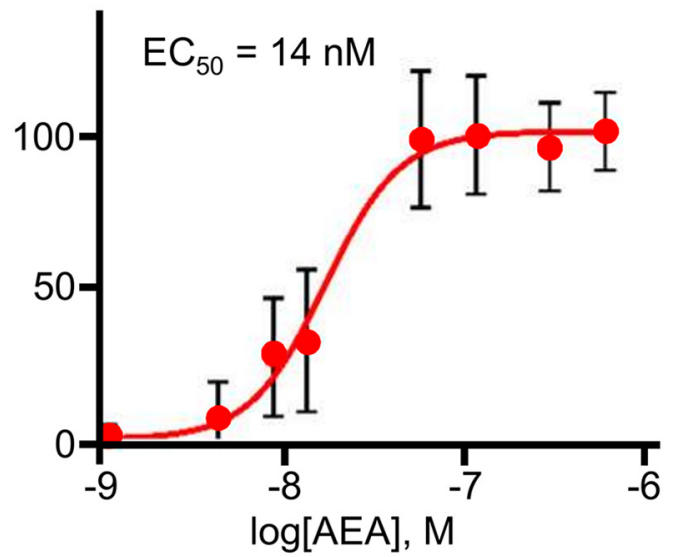

Figure 3. 2-Arachidonoylglycerol (2-AG) and anandamide (AEA) activate NPR-19 expressed in Xenopus laevis oocytes. Two-electrode voltage-clamp (TEVC) recordings were performed on oocytes expressing NPR-19 and GIRK1/2 subunits $72 \mathrm{~h}$ after injection, as described previously (Stühmer, 1998; Bamber et al., 2003). Representative traces are shown for NPR-19 activation by 2-AG (A) and

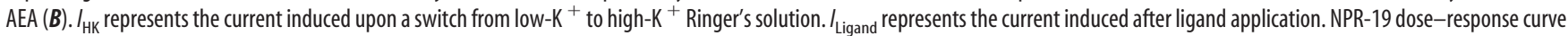
is shown for $2-A G(C)$ and AEA $(\boldsymbol{D})$. Data are represented as a mean \pm SE $(n)$.

and AEA had no effect on oocytes expressing GIRK1/2 alone, but initiated robust inwardly rectifying currents in oocytes expressing NPR-19 (Fig. $3 A, B$ ), with $\mathrm{EC}_{50}$ of $395 \pm 5.1 \mathrm{~nm}$ (Fig. $3 C$ ) and $14 \pm 2.4 \mathrm{~nm}$ (Fig. $3 \mathrm{D}$ ), respectively. The $\mathrm{EC}_{50} \mathrm{~s}$ for $2-\mathrm{AG}$ and $\mathrm{AEA}$ are in the range of $\mathrm{EC}_{50}$ s reported for human $\mathrm{CB}_{1}, 125 \mathrm{nM}$ (Luk et al., 2004) and $89 \mathrm{~nm}$ (McAllister et al., 1999), respectively. Together, these data demonstrate that NPR-19 is a cannabinoid receptor.

\section{NPR-19 is expressed in a limited number of neurons and inhibits pharyngeal pumping and feeding}

Based on fluorescence from an $n p r-19:: g f p$ transgene, NPR-19 is only expressed in a limited number of neurons, including the two inhibitory, glutamatergic M3 pharyngeal motorneurons (Fig. $4 A, B$ ) and the two URX sensory neurons (Fig. $4 A, C$ ) that play key modulatory roles in regulating pharyngeal pumping and avoidance behavior, respectively (Raizen and Avery, 1994; McGrath et al., 2009). As predicted, $n p r-19$ RNAi knockdown in the URXs, using either the URX-selective gpa- 8 or $f l p-8$ promoters, mimicked the npr-19-null phenotype and significantly decreased 2-AG-dependent inhibition of aversive responses to $100 \% 1$-octanol ( $g p a-8: t=13.6, \mathrm{df}=10, p<$ 0.0001; flp-8: $t=16.8, \mathrm{df}=11, p<0.0001$; Fig. $4 D)$. The inhibitory M3s repolarize pharyngeal muscle after contraction and ablation of the M3s decreases the rate of pharyngeal pumping and feeding (Raizen and Avery, 1994). Indeed, 2-AG or AEA also inhibited pharyngeal pumping of food (2-AG: $t=$ $5.2, \mathrm{df}=5, p<0.001$; AEA: $t=5.7, \mathrm{df}=6, p<0.001$; Fig. $4 E)$, although at higher concentrations than those required for the inhibition of nociception ( 320 vs $3.2 \mu \mathrm{M}$ ). In contrast to nociception, JZL184 or URB597 had no effect on pumping (Fig. $4 E$ ), presumably because of the higher cannabinoid levels required for inhibition.

These higher cannabinoid levels also inhibited feeding, as assessed by the uptake of fluorescently labeled latex beads (2AG: $t=6.8, \mathrm{df}=4, p<0.001$; AEA: $t=16.6, \mathrm{df}=4, p<$ 0.0001 ; Fig. $4 G$ ) in wild-type animals. The cannabinoiddependent inhibition of both pumping and feeding were npr-19 dependent and, as predicted, could be rescued by the expression of a full-length $n p r-19$ transgene driven by the predicted $1.5 \mathrm{~kb}$ promoter, including $1 \mathrm{~kb}$ of the npr-19 3'-UTR [pumping (2AG): $t=9.5, \mathrm{df}=11, p<0.001$; pumping (AEA): $t=10.3, \mathrm{df}=$ $10, p<0.0001$; feeding (2-AG): $t=8.2, \mathrm{df}=10, p<0.001$; feeding (AEA): $t=9.0, \mathrm{df}=13, p<0.0001$; Figure $4 F, G]$. More specifically, npr-19 RNAi knockdown in the M3s using either the M3-selective glt-1 or egl-36 promoters, mimicked the npr-19-null 
A

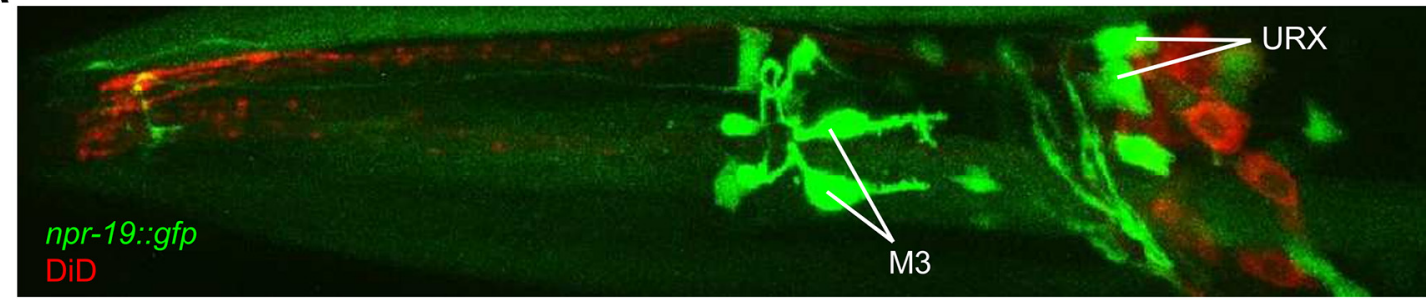

B

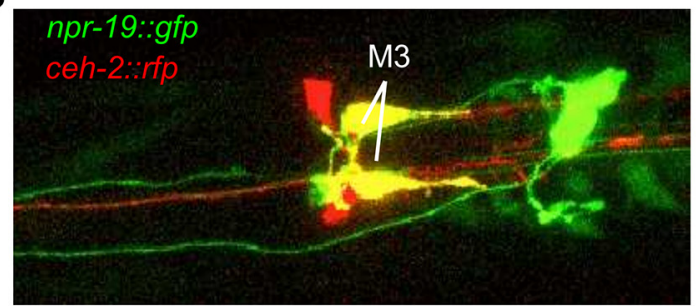

D
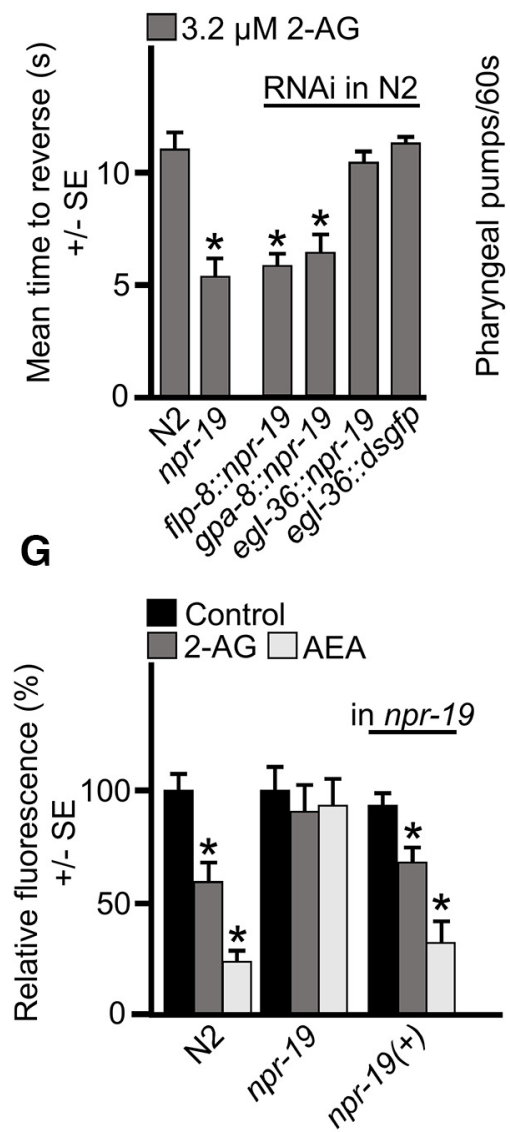

E

E $\quad \square 0 \mu \mathrm{M} \square 3.2 \mu \mathrm{M} \square 32 \mu \mathrm{M}$

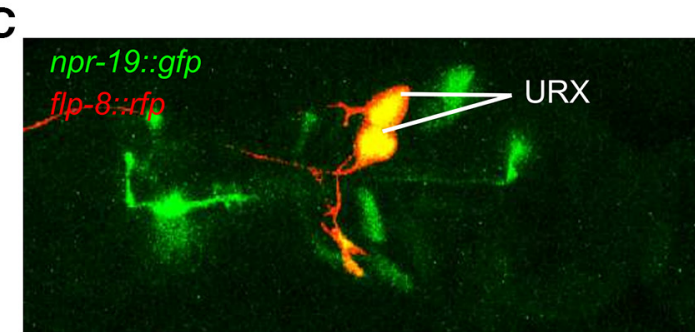

$\mathbf{F}$

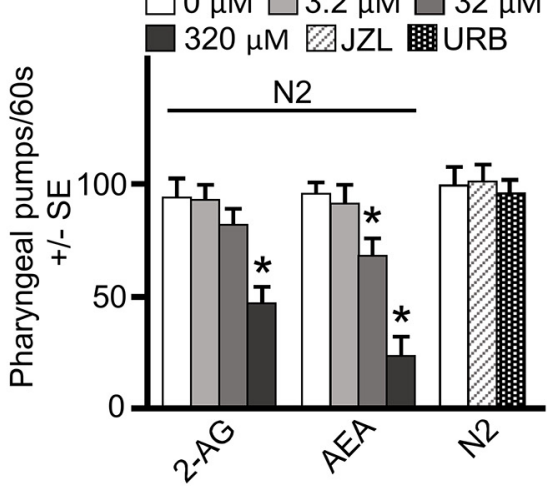

H

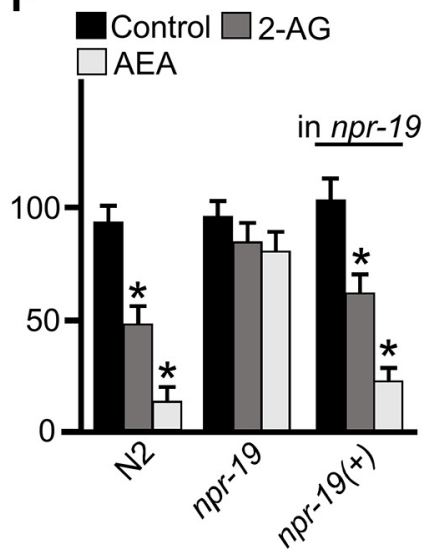

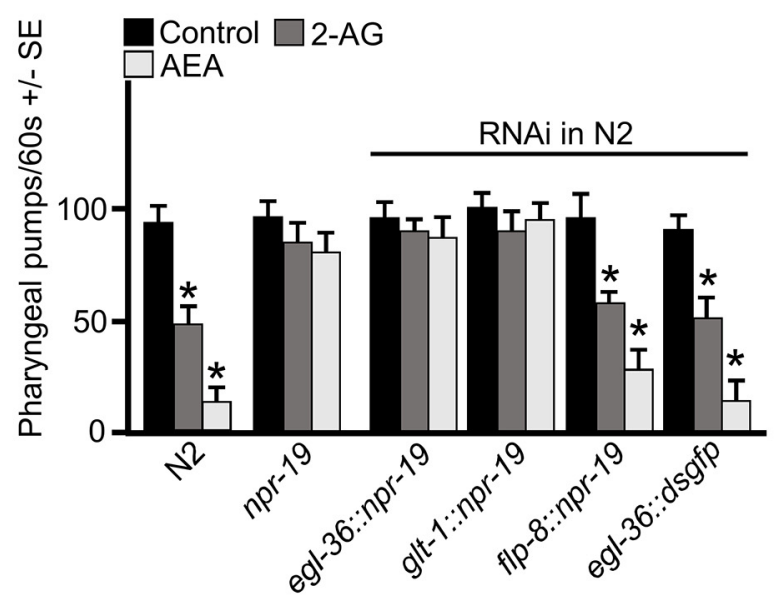

Figure 4. NPR-19 is expressed in a limited number of neurons, including URX and M3.A-C, A transcriptional npr-19::gfp transgene was generated using $1.5 \mathrm{~kb}$ upstream of the predicted npr-19 start site, including the first intron. $A$, DiD-stained wild-type animal expressing npr-19::gfp. B, C, For neuronal identification, npr-19::gfp was coinjected with either flp-8::rfp or ceh-36::rfp. Wild-type animals coexpressing npr-19::gfp and either ceh-2::rfp (B) or ffp-8::rfp (C) were used to identify M3s and URXs, respectively. D, Aversive responses to 1-octanol after selective npr-19 RNAi knockdown in the URXs via flp-8 or gpa-8 promoters. $\boldsymbol{E}$, Concentration-dependent 2-arachidonoylglycerol (2-AG) and anandamide (AEA) inhibition of pharyngeal pumping. $\boldsymbol{F}$, Pharyngeal pumping of npr-19-null and rescue animals. $\mathbf{G}$, Effects of 2-AG/AEA on feeding as measured by the uptake of fluorescentbeads, as described in Kiyama etal. (2012). $\boldsymbol{H}$, Pharyngeal pumping after selectivenpr-19RNAi knockdown in the M3s via egl-36 or $\mathrm{glt}-1$ promoters. flp-8 and gpa-8 promoters drive expression in the two URXs and a limited number of other neurons; egl-36 and glt- 1 promoters drive expression in the two M3s and a limited number of other neurons (Wormbase). * Significantly different from wild-type animals in the absence of effector $(p \leq 0.05)$. Data are presented as a mean \pm SE $(n)$ and were analyzed by two-tailed Student's $t$ test.

phenotype and significantly decreased the 2-AG-dependent inhibition of pharyngeal pumping (Fig. 4H). To ensure that the neuron-specific RNAi phenotypes did not result from transgene overexpression, we expressed a $d s g f p$ RNAi using the same pro- moters. As predicted, these RNAi transgenes had no effect on nociception or feeding (Fig. 4D, H). These data demonstrate key neuron-specific roles for cannabinoids and NPR-19 in the modulation of aversive behavior, pharyngeal pumping, and feeding. 
A

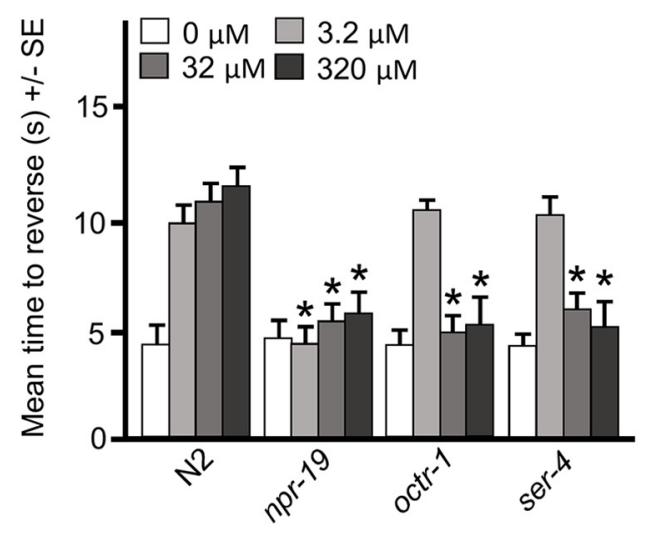

D

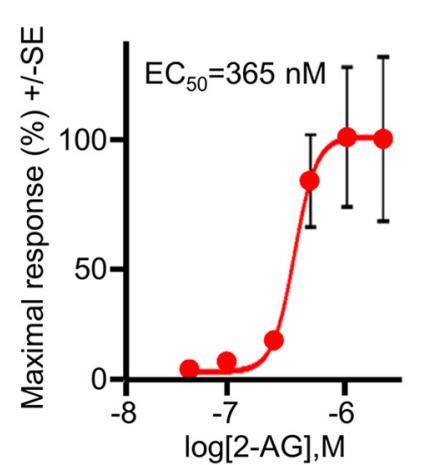

B

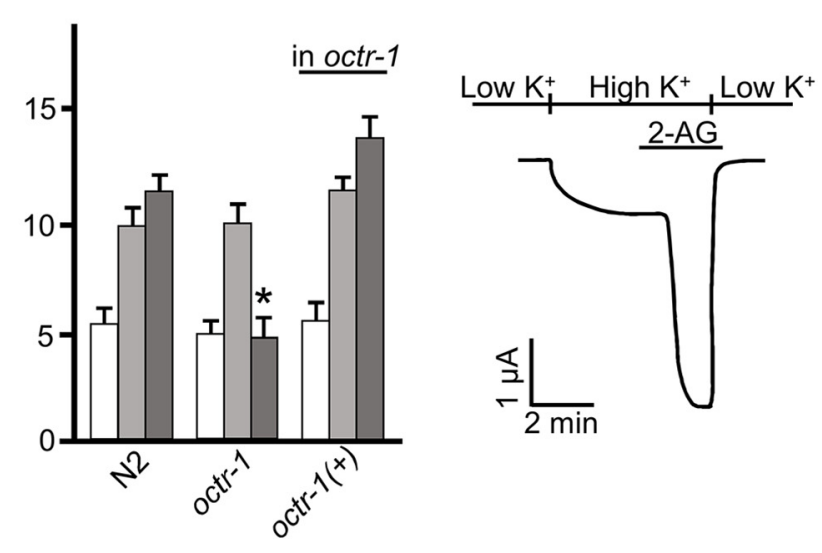

C
E

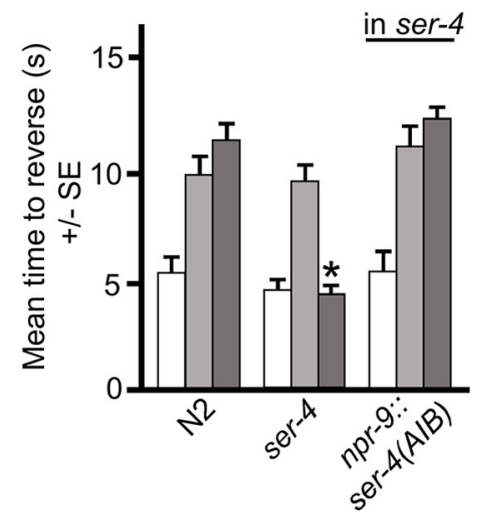

$\mathbf{F}$

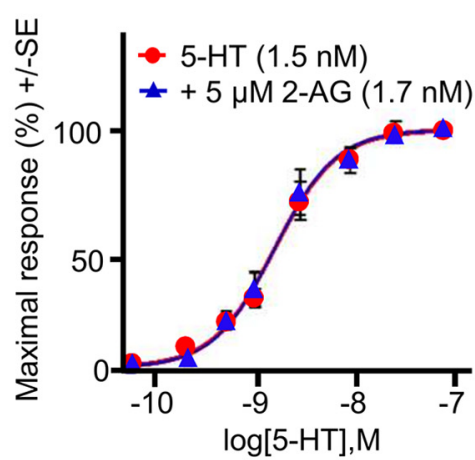

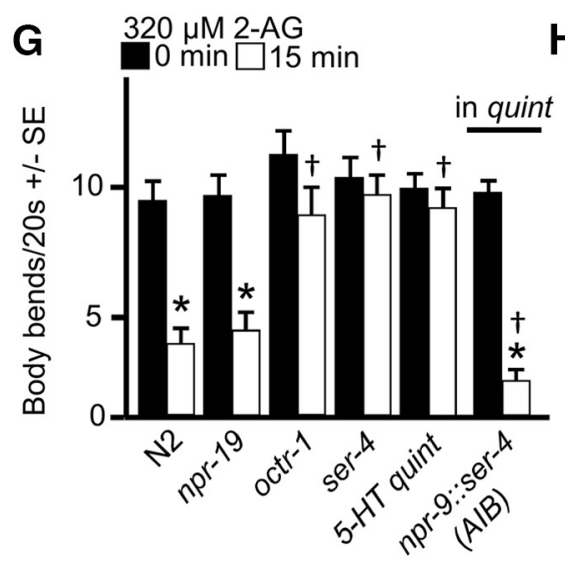

H $\square$ min $\square 15$ min

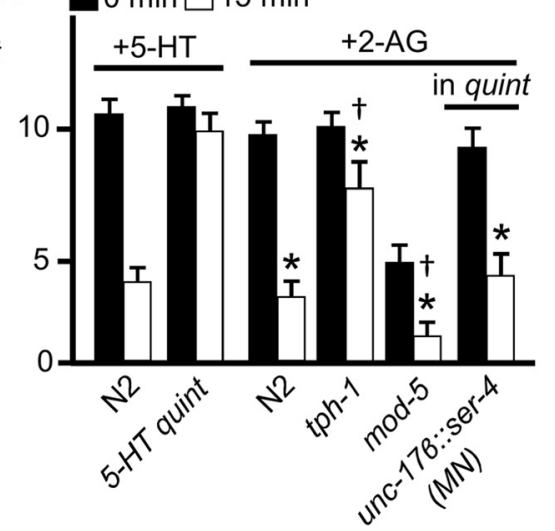

Figure 5. SER-4 and OCTR-1 are required for cannabinoid-dependent inhibition of nociception and locomotion at higher exogenous cannabinoid concentrations. Aversive responses to 1-octanol were examined as described by Harris et al. (2009). A, Concentration-dependent 2-arachidonoylglycerol (2-AG) inhibition of aversive responses. B, octr-1 rescue of 2-AG inhibition of aversive responses in octr-1-null animals. C, D, $\boldsymbol{F}$, Two-electrode voltage-clamp (TEVC) recordings performed on oocytes coexpressing 0CTR- 1 or SER-4 and GIRK1/2 subunits $72 \mathrm{~h}$ after injection, as described previously (Stühmer, 1998; Bamber et al., 2003). C, Representative trace of direct OCTR-1 activation by 2-AG. D, 0CTR-1 dose-response curve for 2-AG. E, 2-AG inhibition of aversive responses to 1-octanol in ser-4-null animals. $\boldsymbol{F}$, SER-4 dose-response curves for serotonin (5-HT) and 5-HT + $5 \mu \mathrm{m}$ 2-AG after SER-4 expression in Xenopus 0ocytes. G-I, 2-AG-dependent locomotory inhibition. $\boldsymbol{H}, 5$-HT- and 2-AG-dependent inhibition of locomotion and 2-AG-dependent locomotory inhibition in 5-HT receptor quintuple-null animals expressing ser-4 off-target in the cholinergic motorneurons (MNs). Data are represented as mean $\pm \mathrm{SE}(n)$ and were analyzed by two-tailed Student's $t$ test. ${ }^{*}$ Significantly different from 0 min; †significantly different from N2 at 15 min $(p \leq 0.05)$.

At higher exogenous cannabinoid concentrations, both serotonin and octopamine $(\mathrm{OA})$ receptors are required for the cannabinoid-dependent inhibition of nociception and locomotion

Because the recreational use of cannabinoids might elevate total cannabinoid levels beyond what were normally observed endogenously, we examined the effects of elevated 2-AG and AEA levels on worm behavior. Surprisingly, at higher exogenous cannabinoid concentrations (32 vs $3.2 \mu \mathrm{M}$ ) the $\alpha_{2 \mathrm{~A}}$-adrenergic-like re- ceptor OCTR-1 and the 5- $\mathrm{HT}_{1}$-like receptor SER-4 are both required for the $2-A G$ inhibition of nociception in addition to NPR-19 because octr-1 and ser-4-null animals are also resistant to 2-AG inhibition (octr-1: $t=7.4$, df $=49, p<0.0001$; ser- 4 : $t=$ 5.8 , $\mathrm{df}=48, p<0.0001$; Fig. $5 A$ ). The monoaminergic modulation of aversive responses is complex and involves the synergistic and antagonistic interactions of multiple monoamine receptors interacting at multiple levels in the locomotory decision-making circuit modulating nociception (Wragg et al., 2007; Harris et al., 
2011; Mills et al., 2012). An octr-1::gfp transgene is broadly expressed, including both the ASHs and the ventral nerve cord (Wragg et al., 2007), and 2-AG sensitivity could be restored in octr- 1 animals by octr -1 expression driven by the predicted $5 \mathrm{~kb}$ octr-1 promoter (Fig. 5B). 2-AG activated OCTR-1 directly after heterologous expression, with an $\mathrm{EC}_{50}$ of $365 \pm 24 \mathrm{~nm}$ (Fig. $5 C, D)$. Interestingly, NPR-19 and OCTR-1 exhibited similar $\mathrm{EC}_{50} \mathrm{~s}$ for 2-AG, although OCTR-1-dependent phenotypes were only observed at higher exogenous $2-A G$ concentrations. These differences could be explained in a number of ways, including differential modulation of the receptors in vivo, differential localization of the receptors relative to ligand entry, or the degree of receptor activation required for the phenotype. In contrast, ser-4 is only expressed in a limited number of neurons and 2-AG sensitivity could be restored in ser-4-null animals by ser-4 expression in the two AIB interneurons (Fig. 5E). In contrast to OCTR-1, 2-AG $(5 \mu \mathrm{M})$ did not activate SER-4 directly and had no effect on SER-4 affinity for 5-HT (Fig. $5 F$ ).

Although MAGL or FAAH inhibition with JZL184 or URB597, respectively, had no effect on locomotion, increasing exogenous cannabinoid levels even further (to $320 \mu \mathrm{M}$ ) also caused animals to become sluggish and stop moving for brief periods $(t=6.7, \mathrm{df}=36, p<0.0001$; Fig. $5 G)$. Both SER-4 and OCTR-1 were involved in this cannabinoid-dependent locomotory inhibition, but, in contrast to aversive responses, NPR-19 was not involved because npr-19-null animals behaved as wildtype animals and were similarly inhibited by $2-\mathrm{AG}(t=3.9, \mathrm{df}=$ 40, $p<0.0001$; Fig. 5G). In fact, this cannabinoid-dependent locomotory phenotype mimicked the 5-HT-dependent "locomotory confusion" phenotype mediated by the 5-HT activation of the $\mathrm{G} \alpha_{\mathrm{o}}$-coupled 5- $\mathrm{HT}_{1}$-like receptor SER-4 in the two AIB interneurons (Law et al., 2015). Indeed, ser-4 and 5-HT receptor quintuple-null animals were both resistant to cannabinoiddependent locomotory inhibition and, as predicted, could be rescued by ser- 4 expression in the AIBs of ser-4-null animals $(t=6.2$, $\mathrm{df}=12, p<0.0001$; Fig. $5 G)$. Interestingly, octr-1-null animals were also resistant, potentially involving the direct 2-AG activation of the inhibitory OCTR-1 in the motorneurons (Fig. 5G). Indeed, octr-1 overexpression inhibited locomotion in the absence of 2-AG compared with wild-type animals ( 6.5 vs 9.6 body bends/20 s; data not shown). These results demonstrate that elevated cannabinoid levels have the potential to stimulate both octopaminergic and serotonergic signaling to modulate an array of key behaviors.

\section{Cannabinoids increase endogenous 5-HT levels}

As noted above, SER-4 was only required at higher exogenous cannabinoid concentrations and 2-AG did not activate SER-4 directly. Therefore, we hypothesized that cannabinoids might increase endogenous 5-HT levels, leading to the locomotory inhibition, either by increasing 5-HT release or inhibiting reuptake. To examine this hypothesis directly, we examined tph-1-null animals that lack tryptophan hydroxylase, the rate-limiting enzyme in 5-HT biosynthesis. As anticipated, tph-1-null animals that lack endogenous 5-HT were resistant to 2-AG-dependent locomotory inhibition $(t=5.1, \mathrm{df}=12, p<0.001)$, suggesting that 5 - HT is required for 2-AG inhibition and that 2-AG may increase endogenous 5-HT (Fig. 5H). Indeed, the 2-AG and 5-HT-dependent locomotory confusion phenotypes are similar and 2-AG-dependent locomotory inhibition mimics that observed in mod-5-null animals that lack a key 5-HT reuptake transporter and also display elevated 5 -HT levels and inhibited locomotion (Fig. $5 \mathrm{H}$ ). However, 2-AG still inhibits locomotion in these already slowed mod-5-null animals $(t=8.2, \mathrm{df}=26, p<0.0001$; Fig. $5 H)$, suggesting additional 2-AG targets, including direct effects on 5-HT release. In addition, 5-HT or 2-AG also inhibit locomotion in transgenic quintuple 5-HT receptor-null animals expressing SER-4 offtarget in the cholinergic motorneurons $(t=3.8, \mathrm{df}=40, p<$ 0.001 ; Fig. $5 I$ ), supporting the observation that $2-\mathrm{AG}$ stimulates global increases in 5-HT. These mutant transgenic animals have been used previously to identify SER-4 agonists for use as potential anthelmintics because the SER-4/G $\alpha_{\mathrm{o}}$-mediated inhibition of the cholinergic motorneurons leads to a rapid flaccid paralysis (Law et al., 2015).

The increased 5-HT levels might also explain the requirement for OCTR-1 in the inhibition of nociception at higher cannabinoid levels because 5-HT stimulates aversive responses in part by activating serotonergic signaling in an array of additional neurons that is antagonized by ASH OCTR-1. Indeed, this complex serotonergic/octopaminergic antagonism in the modulation of ASH-dependent aversive responses has been characterized previously, with at least three different 5-HT receptors, SER-1, SER-5, and MOD-1, involved in stimulating the initiation of aversive responses (Wragg et al., 2007; Harris et al., 2009; Mills et al., 2012). Together, these data highlight the complex interaction among cannabinoid, serotonergic, and octopaminergic signaling and suggest that they may also be relevant to understanding the role of exogenous cannabinoids in the modulation of human behavior because $C$. elegans has proven previously to be a useful model for understanding monoaminergic modulation in mammals (Komuniecki et al., 2012; Mills et al., 2012) (Fig. 6).

\section{Discussion}

The present study demonstrates that $C$. elegans contains an endogenous cannabinoid signaling system that modulates an array of key behaviors (Fig. 6). For example, the endocannabinoids 2-AG and AEA inhibit both aversive behavior and feeding. 2-AG and AEA have been identified previously in $C$. elegans extracts by GC/MS (Lehtonen et al., 2011). In contrast to previous reports suggesting that $C$. elegans does not contain a canonical cannabinoid receptor (McPartland et al., 2001), although a mutant screen did identify that the predicted neuropeptide receptor, NPR-19 was involved in the effects of cannabinoids on axon regeneration in C. elegans (Pastuhov et al., 2016). In the present study, we have demonstrated that NPR-19 is essential for many cannabinoid-dependent behaviors and responds directly to cannabinoid ligands with high affinity. Indeed, although $\mathrm{G} \alpha_{\mathrm{o}}$-coupled NPR-19 exhibits only $23 \%$ identity to the human $\mathrm{G} \alpha_{\mathrm{o}}$-coupled cannabinoid receptor $\mathrm{CB}_{1}$, many of the key amino acids involved in ligand binding are conserved in the two receptors and phenotypes in $n$ pr-19-null animals could be rescued by the expression of human CB1, confirming the orthology of the two receptors (McPartland et al., 2001).

These cannabinoid ligands also activate octopaminergic and serotonergic signaling by functioning as agonists for the $\alpha_{2 \mathrm{~A}}$-adrenergic-like OA receptor OCTR-1 and increasing endogenous 5-HT. This is based on the observations that 5-HT mimics the inhibitory effects of $2-\mathrm{AG}$ on locomotion and that the 2-AG inhibition of both nociception and locomotion is significantly reduced in tph-1-null animals that lack a key 5 -HT biosynthetic enzyme and have dramatically reduced 5-HT levels. The monoaminergic modulation of aversive responses to 1-octanol is complex and involves multiple sensory neurons and an array of monoamine receptors. For example, 5-HT stimulates the initiation of an ASH-dependent aversive 


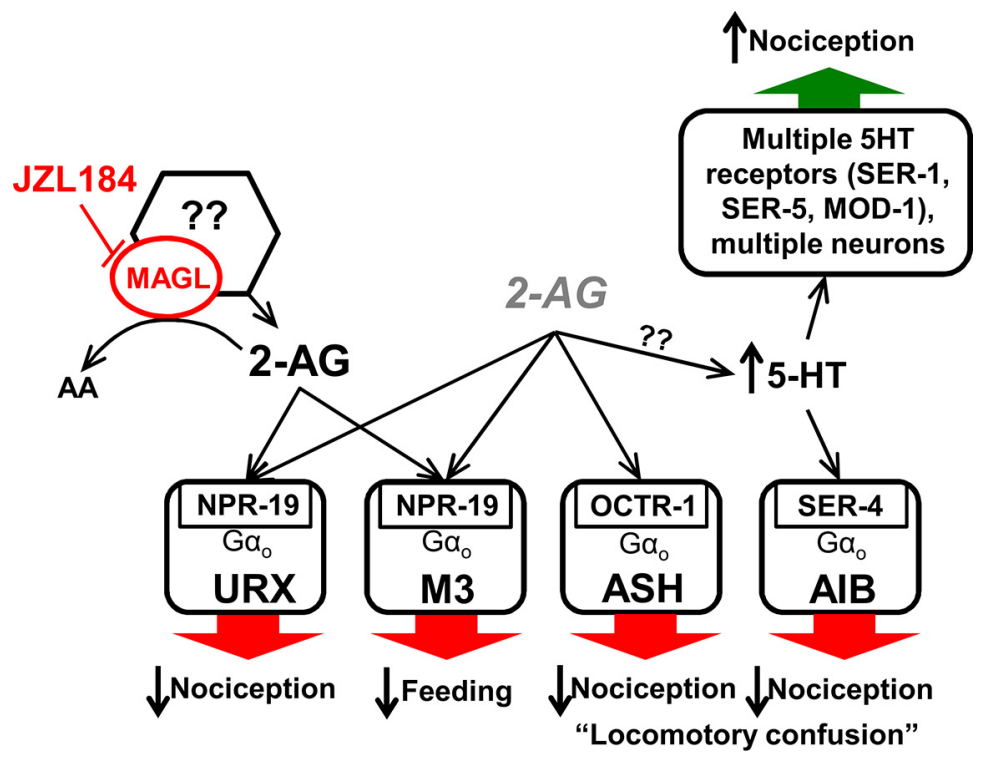

Figure 6. Model of 2-arachidonoylglycerol (2-AG)-dependent modulation of behavior. Endogenous 2-AG activates NPR-19 in the URXs to inhibit nociception. In addition, at higher 2-AG levels via exogenous application, 2-AG (italic gray) also activated NPR-19 to inhibit pharyngeal and feeding and also activated directly and indirectly a number of monoamine receptors to inhibit locomotion through an NPR-19-independent mechanism. These elevated 2-AG levels appear to increase endogenous serotonin (5-HT) and activate SER-4 in the two AIB interneurons to initiate locomotory confusion and paralysis that has been characterized previously (Law et al., 2015). Interestingly, 5-HT stimulates the initiation of aversive responses by activation of at least three additional 5-HT receptors, each operating at different levels within the ASHdependent aversive circuit (Harris et al., 2011). However, this potential 5-HT stimulation appears to be overcome by the direct 2-AG activation of the $\alpha_{2 \mathrm{~A}}$-adrenergic-like OA receptor OCTR-1 in the ASHs to inhibit 5-HT-stimulated aversive responses, as demonstrated previously (Wragg et al., 2007). MAGL degrades 2-AG and terminates signaling and JZL184, an MAGL inhibitor, increases endogenous 2-AG levels and mimics the application of low levels of 2-AG.

response and requires three distinct 5-HT receptors operating at different levels within the locomotory circuit (Harris et al., 2009), with 5-HT decreasing ASH calcium but increasing ASH depolarization and activity (Zahratka et al., 2015). In contrast, OA antagonizes this 5-HT-dependent stimulation via the G $\alpha_{\mathrm{o}}$-coupled $\alpha_{2}$-adrenergic-like OA receptor OCTR-1, inhibiting the ASHs directly and the $\mathrm{G} \alpha_{\mathrm{q}}$-coupled OA receptor SER-6, which stimulates the release of an additional layer of inhibitory monoamines and neuropeptides (Mills et al., 2012). Indeed, this octopaminergic modulation of nociception, with a $\mathrm{G} \alpha_{\mathrm{o}}$-coupled receptor inhibiting the primary nociceptor and a $\mathrm{G} \alpha_{\mathrm{q}}$-coupled receptor stimulating the release of multiple inhibitory neuropeptides, mimics the noradrenergic modulation of chronic pain in humans (Komuniecki et al., 2012). The levels of OA appear to be critical for the inhibitory response because OA inhibition is masked at higher OA concentrations by activation of a second antagonistic $\mathrm{G} \alpha$-coupled OA receptor, SER-3, in the ASHs, highlighting the delicate and dynamic balance of this modulatory system (Wragg et al., 2007). At low levels of cannabinoid receptor ligands, achieved by either inhibition of their endogenous breakdown or exogenous application, behaviors appear to be modulated exclusively by NPR-19. However, at higher levels of exogenous addition, both the octopaminergic and serotonergic signaling systems are activated. Indeed, it was puzzling at first why SER-4 and OCTR-1 were only required for the inhibition of nociception at higher cannabinoid concentrations. However, we propose that these higher cannabinoid concentrations increase endogenous 5-HT and its potential stimulation of aversive responses must be antagonized by ASH OCTR-1 for the cannabinoid-dependent inhibition of nociception to be realized. C. elegans contains multiple serotonergic neu- rons that function independently in the modulation of key behaviors. For example, global 5-HT released by the two neurosecretory NSMs stimulates the initiation of aversive responses to 1 -octanol, whereas more local 5-HT from the ADFs appears to inhibit this response (Song et al., 2013). In contrast, ADF 5-HT is responsible for the increased pharyngeal pumping associated with the presence of food, whereas the NSMs located directly above the pharynx apparently are not involved. Interestingly, 2-AG dramatically inhibited the 5-HT quintuple-null animals expressing the inhibitory $5-\mathrm{HT}_{1 \mathrm{~A}}$-like receptor SER-4 off target in the cholinergic motor neurons, suggesting that cannabinoids initiate a more global increase in 5-HT. Whether this results from the direct and/or indirect stimulation of secretion by the NSMs or the inhibition of 5-HT reuptake is unclear, but the locomotory confusion phenotype initiated by either 5 -HT or 2-AG is mimicked by knockdown of the key 5-HT reuptake transporter MOD-5. Cannabinoid receptor agonists also modulate $\alpha$-adrenergic and serotonergic signaling in mammals and function as agonists for the human $\alpha_{2 \mathrm{~A}^{-}}$ adrenergic receptor. For example, cannabinoid receptor stimulation activates the hypothalamic-pituitary-adrenal axis because central administration of THC in rats leads to an increase in plasma adrenocorticotrophin hormone levels (Corchero et al., 1999) and in the expression of corticotrophin releasing hormone mRNA in the anterior pituitary (Corchero et al., 2001). 2-AG increases norepinephrine (NE) release (Kurihara et al., 2001) and AEA or HU-210, a synthetic $\mathrm{CB}_{1}$ agonist, significantly increases the level of circulating corticosterone (McLaughlin et al., 2009). In fact, interactions between endogenous cannabinoid and noradrenergic signaling have been observed in a number of organ systems. For example, cannabinoid receptor signaling plays a role in noradrenergic splenic contraction and interacts with adrenergic systems in the prefrontal cortex (Simkins et al., 2016). In addition, cannabinoids can block neuronal NE uptake and the phytocannabinoid cannabigerol functions as a $\alpha_{2}$-adrenoceptor agonist in isolated mouse vas deferens (Cascio et al., 2010). Cannabinoids also modulate the synthesis, release, and turnover of 5-HT and appear to inhibit 5-HT reuptake and enhance 5- $\mathrm{HT}_{1 \mathrm{~A}}$ signaling (Egashira et al., 2002; Sagredo et al., 2006). For example, both endogenous and synthetic cannabinoids inhibit 5-HT reuptake in rats and chronic THC administration increases endogenous 5-HT levels in the prefrontal cortex of rats. In addition, the phytocannabinoid $\Delta^{9}$-tetrahydrocannabivarin appears to act through $5-\mathrm{HT}_{1 \mathrm{~A}}$ receptors to produce antipsychotic effects by functioning as an allosteric modulator, increasing the efficacy but not the $\mathrm{EC}_{50}$ of the potent $5-\mathrm{HT}_{1 \mathrm{~A}}$ agonist $8-\mathrm{OH}$ DPAT (Cascio et al., 2015). Together, these observations highlight the similarities between the nematode and mammalian cannabinoid signaling system and the potential of the $C$. elegans whole-animal model for the study of cannabinoid/ monoamine interactions. 


\section{References}

Bamber BA, Twyman RE, Jorgensen EM (2003) Pharmacological characterization of the homomeric and heteromeric UNC-49 GABA receptors in $C$. elegans. Br J Pharmacol 138:883-893. CrossRef Medline

Brenner S (1974) The genetics of Caenorhabditis elegans. Genetics 77:71-94. Medline

Cascio MG, Gauson LA, Stevenson LA, Ross RA, Pertwee RG (2010) Evidence that the plant cannabinoid cannabigerol is a highly potent alpha2adrenoceptor agonist and moderately potent $5 \mathrm{HT} 1 \mathrm{~A}$ receptor antagonist. Br J Pharmacol 159:129-141. CrossRef Medline

Cascio MG, Zamberletti E, Marini P, Parolaro D, Pertwee RG (2015) The phytocannabinoid, Delta(9)-tetrahydrocannabivarin, can act through 5-HT(1)A receptors to produce antipsychotic effects. Br J Pharmacol 172: 1305-1318. CrossRef Medline

Chao MY, Komatsu H, Fukuto HS, Dionne HM, Hart AC (2004) Feeding status and serotonin rapidly and reversibly modulate a Caenorhabditis elegans chemosensory circuit. Proc Natl Acad Sci U S A 101:15512-15517. CrossRef Medline

Clapper JR, Moreno-Sanz G, Russo R, Guijarro A, Vacondio F, Duranti A, Tontini A, Sanchini S, Sciolino NR, Spradley JM, Hohmann AG, Calignano A, Mor M, Tarzia G, Piomelli D (2010) Anandamide suppresses pain initiation through a peripheral endocannabinoid mechanism. Nat Neurosci 13:1265-1270. CrossRef Medline

Corchero J, Manzanares J, Fuentes JA (1999) Repeated administration of delta9-tetrahydrocannabinol produces a differential time related responsiveness on proenkephalin, proopiomelanocortin and corticotropin releasing factor gene expression in the hypothalamus and pituitary gland of the rat. Neuropharmacology 38:433-439. CrossRef Medline

Corchero J, Manzanares J, Fuentes JA (2001) Role of gonadal steroids in the corticotropin-releasing hormone and proopiomelanocortin gene expression response to Delta(9)-tetrahydrocannabinol in the hypothalamus of the rat. Neuroendocrinology 74:185-192. CrossRef Medline

Egashira N, Mishima K, Iwasaki K, Fujiwara M (2002) Intracerebral microinjections of delta 9-tetrahydrocannabinol: search for the impairment of spatial memory in the eight-arm radial maze in rats. Brain Res 952:239245. CrossRef Medline

Esposito G, Di Schiavi E, Bergamasco C, Bazzicalupo P (2007) Efficient and cell specific knock-down of gene function in targeted C. elegans neurons. Gene 395:170-176. CrossRef Medline

Glass M, Dragunow M, Faull RL (1997) Cannabinoid receptors in the human brain: a detailed anatomical and quantitative autoradiographic study in the fetal, neonatal and adult human brain. Neuroscience 77:299-318. CrossRef Medline

Harris GP, Hapiak VM, Wragg RT, Miller SB, Hughes LJ, Hobson RJ, Steven R, Bamber B, Komuniecki RW (2009) Three distinct amine receptors operating at different levels within the locomotory circuit are each essential for the serotonergic modulation of chemosensation in Caenorhabditis elegans. J Neurosci 29:1446-1456. CrossRef Medline

Harris G, Korchnak A, Summers P, Hapiak V, Law WJ, Stein AM, Komuniecki P, Komuniecki R (2011) Dissecting the serotonergic food signal stimulating sensory-mediated aversive behavior in C. elegans. PLoS One 6:e21897. CrossRef Medline

Herkenham M, Lynn AB, Little MD, Johnson MR, Melvin LS, de Costa BR, Rice KC (1990) Cannabinoid receptor localization in brain. Proc Natl Acad Sci U S A 87:1932-1936. CrossRef Medline

Hobert O (2002) PCR fusion-based approach to create reporter gene constructs for expression analysis in transgenic C. elegans. Biotechniques 32: 728-730. Medline

Iskedjian M, Bereza B, Gordon A, Piwko C, Einarson TR (2007) Metaanalysis of cannabis based treatments for neuropathic and multiple sclerosis-related pain. Curr Med Res Opin 23:17-24. CrossRef Medline

Kiyama Y, Miyahara K, Ohshima Y (2012) Active uptake of artificial particles in the nematode Caenorhabditis elegans. J Exp Biol 215:1178-1183. CrossRef Medline

Komuniecki R, Harris G, Hapiak V, Wragg R, Bamber B (2012) Monoamines activate neuropeptide signaling cascades to modulate nociception in C. elegans: a useful model for the modulation of chronic pain? Invertebrate neuroscience: IN 12:53-61. CrossRef Medline

Kurihara J, Nishigaki M, Suzuki S, Okubo Y, Takata Y, Nakane S, Sugiura T, Waku K, Kato H (2001) 2-Arachidonoylglycerol and anandamide oppositely modulate norepinephrine release from the rat heart sympathetic nerves. Jpn J Pharmacol 87:93-96. CrossRef Medline
Law W, Wuescher LM, Ortega A, Hapiak VM, Komuniecki PR, Komuniecki R (2015) Heterologous expression in remodeled C. elegans: a platform for monoaminergic agonist identification and anthelmintic screening. PLoS Pathog 11:e1004794. CrossRef Medline

Lehtonen M, Storvik M, Malinen H, Hyytiä P, Lakso M, Auriola S, Wong G, Callaway JC (2011) Determination of endocannabinoids in nematodes and human brain tissue by liquid chromatography electrospray ionization tandem mass spectrometry. J Chromatogr B Analyt Technol Biomed Life Sci 879:677-694. CrossRef Medline

Long JZ, Nomura DK, Cravatt BF (2009a) Characterization of monoacylglycerol lipase inhibition reveals differences in central and peripheral endocannabinoid metabolism. Chem Biol 16:744-753. CrossRef Medline

Long JZ, Nomura DK, Vann RE, Walentiny DM, Booker L, Jin X, Burston JJ, Sim-Selley LJ, Lichtman AH, Wiley JL, Cravatt BF (2009b) Dual blockade of FAAH and MAGL identifies behavioral processes regulated by endocannabinoid crosstalk in vivo. Proc Natl Acad Sci U S A 106:2027020275. CrossRef Medline

Luk T, Jin W, Zvonok A, Lu D, Lin XZ, Chavkin C, Makriyannis A, Mackie K (2004) Identification of a potent and highly efficacious, yet slowly desensitizing CB1 cannabinoid receptor agonist. Br J Pharmacol 142:495-500. CrossRef Medline

Martin WJ, Tsou K, Walker JM (1998) Cannabinoid receptor-mediated inhibition of the rat tail-flick reflex after microinjection into the rostral ventromedial medulla. Neurosci Lett 242:33-36. CrossRef Medline

McAllister SD, Griffin G, Satin LS, Abood ME (1999) Cannabinoid receptors can activate and inhibit $\mathrm{G}$ protein-coupled inwardly rectifying potassium channels in a Xenopus oocyte expression system. J Pharmacol Exp Ther 291:618-626. Medline

McAllister SD, Rizvi G, Anavi-Goffer S, Hurst DP, Barnett-Norris J, Lynch DL, Reggio PH, Abood ME (2003) An aromatic microdomain at the cannabinoid $\mathrm{CB}(1)$ receptor constitutes an agonist/inverse agonist binding region. J Med Chem 46:5139-5152. CrossRef Medline

McAllister SD, Hurst DP, Barnett-Norris J, Lynch D, Reggio PH, Abood ME (2004) Structural mimicry in class A G protein-coupled receptor rotamer toggle switches: the importance of the F3.36(201)/W6.48(357) interaction in cannabinoid CB1 receptor activation. J Biol Chem 279:4802448037. CrossRef Medline

McGrath PT, Rockman MV, Zimmer M, Jang H, Macosko EZ, Kruglyak L, Bargmann CI (2009) Quantitative mapping of a digenic behavioral trait implicates globin variation in C. elegans sensory behaviors. Neuron 61: 692-699. CrossRef Medline

McLaughlin RJ, Hill MN, Gorzalka BB (2009) Monoaminergic neurotransmission contributes to cannabinoid-induced activation of the hypothalamic-pituitaryadrenal axis. Eur J Pharmacol 624:71-76. CrossRef Medline

McPartland JM, Glass M (2001) Nematicidal effects of hemp (Cannabis sativa) may not be mediated by cannabinoid receptors. New Zeal J Crop Hort 29:301-307. CrossRef

McPartland J, Di Marzo V, De Petrocellis L, Mercer A, Glass M (2001) Cannabinoid receptors are absent in insects. J Comp Neurol 436:423-429. CrossRef Medline

Mills H, Wragg R, Hapiak V, Castelletto M, Zahratka J, Harris G, Summers P, Korchnak A, Law W, Bamber B, Komuniecki R (2012) Monoamines and neuropeptides interact to inhibit aversive behaviour in Caenorhabditis elegans. EMBO J 31:667-678. CrossRef Medline

Munro S, Thomas KL, Abu-Shaar M (1993) Molecular characterization of a peripheral receptor for cannabinoids. Nature 365:61-65. CrossRef Medline

Ohno-Shosaku T, Kano M (2014) Endocannabinoid-mediated retrograde modulation of synaptic transmission. Curr Opin Neurobiol 29:1-8. CrossRef Medline

Pacher P, Bátkai S, Kunos G (2006) The endocannabinoid system as an emerging target of pharmacotherapy. Pharmacol Rev 58:389-462. CrossRef Medline

Pastuhov SI, Matsumoto K, Hisamoto N (2016) Endocannabinoid signaling regulates regenerative axon navigation in Caenorhabditis elegans via the GPCRs NPR-19 and NPR-32. Genes Cells 21:696-705. CrossRef Medline

Piomelli D, Tarzia G, Duranti A, Tontini A, Mor M, Compton TR, Dasse O, Monaghan EP, ParrottJA, Putman D (2006) Pharmacological profile of the selective FAAH inhibitor KDS-4103 (URB597). CNS Drug Rev 12:21-38. CrossRef Medline

Raizen DM, Avery L (1994) Electrical activity and behavior in the pharynx of Caenorhabditis elegans. Neuron 12:483-495. CrossRef Medline

Reggio PH (2010) Endocannabinoid binding to the cannabinoid receptors: 
what is known and what remains unknown. Curr Med Chem 17:14681486. CrossRef Medline

Sagredo O, Ramos JA, Fernández-Ruiz J, Rodríguez ML, de Miguel R (2006) Chronic Delta9-tetrahydrocannabinol administration affects serotonin levels in the rat frontal cortex. Naunyn Schmiedebergs Arch Pharmacol 372:313-317. CrossRef Medline

Simkins TJ, Fried D, Parikh K, Galligan JJ, Goudreau JL, Lookingland KJ, Kaplan BL (2016) Reduced noradrenergic signaling in the spleen capsule in the absence of CB1 and CB2 cannabinoid receptors. J Neuroimmune Pharmacol

Sofia RD, Nalepa SD, Harakal JJ, Vassar HB (1973) Anti-edema and analgesic properties of delta9-tetrahydrocannabinol (THC). J Pharmacol Exp Ther 186:646-655. Medline

Song BM, Faumont S, Lockery S, Avery L (2013) Recognition of familiar food activates feeding via an endocrine serotonin signal in Caenorhabditis elegans. Elife 2:e00329. CrossRef Medline

Stühmer W (1998) Electrophysiologic recordings from Xenopus oocytes. Methods Enzymol 293:280-300. CrossRef Medline
Tsou K, Patrick SL, Walker JM (1995) Physical withdrawal in rats tolerant to delta 9-tetrahydrocannabinol precipitated by a cannabinoid receptor antagonist. Eur J Pharmacol 280:R13-R15. CrossRef Medline

Walker JM, Huang SM (2002) Endocannabinoids in pain modulation. Prostaglandins Leukot Essent Fatty Acids 66:235-242. CrossRef Medline

Wragg RT, Hapiak V, Miller SB, Harris GP, Gray J, Komuniecki PR, Komuniecki RW (2007) Tyramine and octopamine independently inhibit serotonin-stimulated aversive behaviors in Caenorhabditis elegans through two novel amine receptors. J Neurosci 27:13402-13412. CrossRef Medline

Yaksh TL, Reddy SV (1981) Studies in the primate on the analgetic effects associated with intrathecal actions of opiates, alpha-adrenergic agonists and baclofen. Anesthesiology 54:451-467. CrossRef Medline

Zahratka JA, Williams PD, Summers PJ, Komuniecki RW, Bamber BA (2015) Serotonin differentially modulates Ca2 + transients and depolarization in a C. elegans nociceptor. J Neurophysiol 113:1041-1050. CrossRef Medline 